\title{
Trends In Green Agribusiness: A Look At Anaerobic Digesters
}

Tom Bramorski, University of Wisconsin-Whitewater, USA

\begin{abstract}
The need to reduce emissions that pollute the environment has been well documented. In many studies agriculture has been identified as one of the major contributors to environmental contamination. In this paper we discuss anaerobic digesters as a way to reduce agricultural contamination of the environment and generate electrical energy. We also discuss select cases of Midwestern farms that implemented the technology.
\end{abstract}

\section{INTRODUCTION}

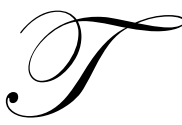

here are several technologies to produce energy while significantly reducing or eliminating greenhouse gas emissions. These technologies include solar, wind, geothermal, bio fuel, tidal, and nuclear power. This paper focuses on bio fuel, and more specifically, on using methane emitted from cow manure to generate heat and electrical energy. In the Midwestern United States anaerobic digesters have been used for many years but for economic and political reasons, their use has been limited to large farms with herd sizes of well over 1,000. Due to recent technological progress anaerobic digesters are now being successfully used in midsized farms of 500 cows. Economic feasibility of these new technologies is also being examined at test at facilities with even smaller herd sizes.

Factors influencing the decision to install anaerobic digesters include a decrease of energy costs, reduction of odor problems, and manure handling improvements. An electric company will typically buy excess energy produced from the digester's generator. This helps offset the significant costs involved with installation and operation of the digester making the venture more profitable over its life cycle. The technology used in anaerobic digesters has been in operation for many years by municipalities that have utilized this method for managing some of their waste. However, the escalating energy costs and digester process improvements have enticed farms to consider the option in recent years. Emphasis on environmental protection combined with the implementation of public policies encouraging the deployment of "green" technologies has stimulated interest in methane digestion.

Figure 1 outlines the basic stages in waste utilization process the important in modern farming operations. Consider waste collected from the livestock. This input is often blended with water to create a liquid suspension that flows to the next process stage. Here the digestion process takes place producing methane gas which is captured for further processing. The material used in the digester is moved into a separator to create a liquid that can be used for fertilizer, and the solid compound having many potential uses including bedding, mulch, and soil additive. Waste collected from the livestock may also contain natural bedding such as shredded newspaper, or wood shavings. Anaerobic digestion helps to improve the quality of fertilizer produced. Solid waste decomposes during this process because of the fermentation process of organic matter that also allows the nitrogen to break down into simpler forms making it easier for plants to absorb and utilize. The microorganisms that break down livestock waste produce methane that is captured for further processing.

\section{OVERVIEW OF THE ANAEROBIC DIGESTION PROCESS AND EQUIPMENT TYPES}

Methane has been used through the process of anaerobic digestion to produce energy using renewable resources including municipal sludge, sewage, and animal manure. The process produces liquid by-products left after the digestion. Such liquids can be separated and used for fertilizer while solids can be used for multiple purposes including mulch, bedding, and soil additives. Energy generated when the methane gas is burned can be 
captured and converted to electricity for internal use on a farm, with excess sold to energy companies. Thermal energy that is generated can be used to boil water to use to heat areas near the digester, and also for use in operation around the farm where hot or warm water is needed. Methane gas production occurs in a three step process: (1) diluting the waste matter, (2) producing acid, and (3) producing methane (Hansen, 2007). By diluting the manure, the solids are broken down into smaller particles that can be more efficiently used by the organisms used in decomposition. These organisms process the organic matter, ferment the mixture, and produce methane, which is clear, tasteless, and odorless gas. It is lighter than air, and is generally non-toxic to breathe (unless the concentration of it is so high that there is not enough oxygen in the air to support life). Like many industrial process gases, methane is considered a greenhouse gas, which remains in the atmosphere for as many as 15 years before decomposing (Anonymous, 2009).

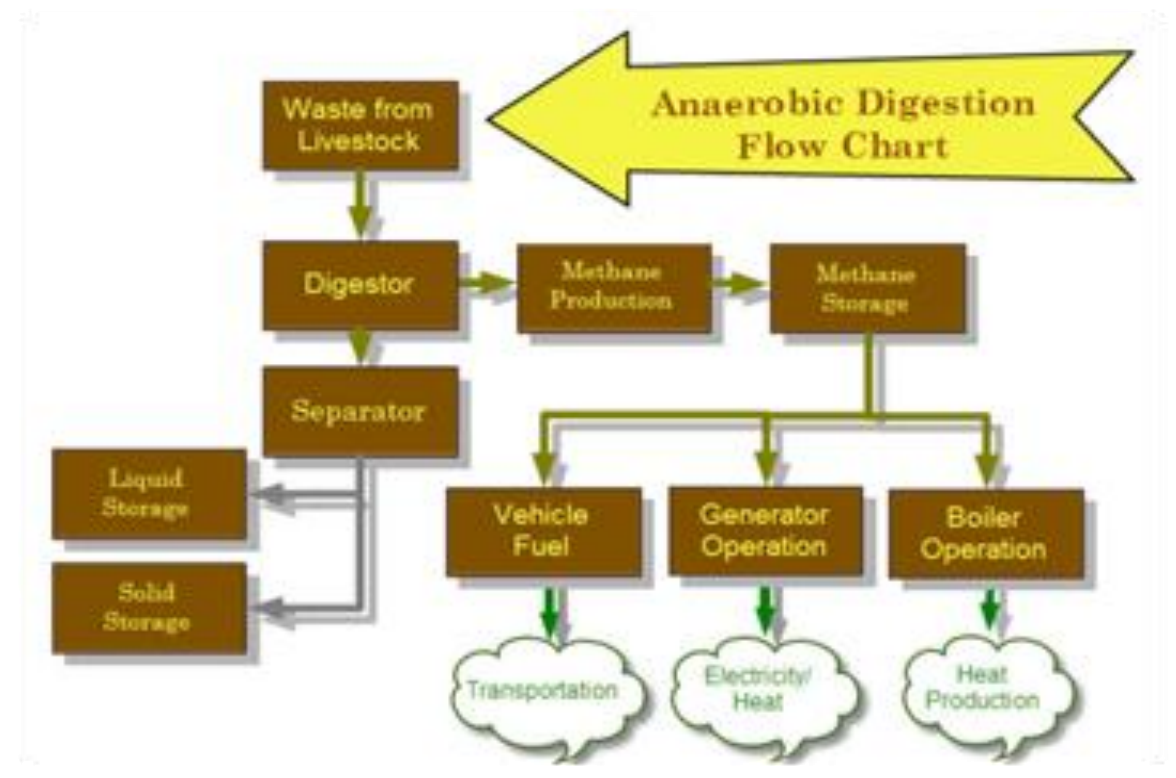

Figure 1. Steps involved in anaerobic digestion process on farms

Methane is second only to carbon dioxide for its negative impact on climate. The rising level of methane in the atmosphere has been caused by numerous factors, including the increase of human and livestock populations. However, the process of capturing and burning methane releases less carbon dioxide into the air, and produces more energy than many of the other fuels. Pure methane concentration generated in digesters is between $50-70$ percent. Comparing the calorific value of methane to gasoline, the octane rating of regular gas in the United States is between 87 and 93 while methane has an octane rating of between 120 and 130. From a business perspective this has made utilization of organic waste a viable alternative to fossil fuels (Sullivan, 2007) and (Gross, 2002). Yet, the number of operating digesters in the United States is very small. In 2008 and 2009 there were 73 anaerobic digesters capturing manure energy already in operation in the Midwest with only 20 new ones due to start operation in early 2010. Overall, there are over 260 agricultural anaerobic digesters have been registered with the EPA nationwide (United States Environmental Protection Agency, 2009).

Temperature plays an important role in methane production. The bacteria are most active in two temperature ranges, 35 to 40.6 degrees Celsius and 54.4 to 57.2 degrees Celsius (Farms, 2001). In order to maintain these temperatures some digesters have water pipes that run through the device. Once methane gas has been produced and captured, it is channelled to the generator to produce electricity. Excess gas is burned off to heat/boil water to maintain the required digester operating temperature range as well as to heat the buildings surrounding the digester operation.

The most common types of digesters include covered lagoons, complete mix, and plug-flow. The covered lagoon digester contains a membrane spanning the entire lagoon where liquid slurry of manure is stored. The 
targeted percentage of solids is only around 2 percent. Because this type of digester is normally not heated, this system works best in climates that stay warm year round. The complete mix digester handles a mixture of up to 10 percent solid waste. Dairy or swine manure flushed into this system is common. The tanks are heated and can be built above or below the ground. To maintain optimal methane production the liquid suspension is continuously agitated to keep the solids from settling. The plug flow digester operates with slurry containing 11 to 14 percent solids. Lower concentrations of solids are not desired for this system because they settle out to the bottom of the tank. With few moving parts, this system has minimal maintenance and operating costs.

A very promising and newer type digester is the temperature-phased anaerobic digestion (TPAD) system developed in Iowa. This system operates in two stages, one at the higher active temperature range (57.2 degrees Celsius), and the second at the lower range (35 degrees Celsius). The system can use manures with lower solid concentrations, such as the product from dairy and swine operations. Because of its relative novelty, data available for this application is very limited. The advantages of this system appear promising, but further research and testing needs to be performed to determine technological and economic feasibility.

A covered lagoon digester, shown in Figure 2, is built with a large hole or pit. Constructed with wither soil, or concrete walls it is the least expensive of the main digester types. It is very simple in design and its influent and effluent locations are on the sides of the pit. Some of the covered lagoon type digesters contain auxiliary pumps to remove excess effluent creating proper flow and reduce clogging. The covering over the lagoon is typically a durable canvas, but in some cases a concrete lid may be fashioned and sealed. The biogas effluent containing methane is also removed from the tank and sent to a storage vessel. The lagoon tank could be used to manage 700 head of cattle and hold a day's quantity of influent for approximately 15 days (Office of Air and Radiation, EPA, 2002).

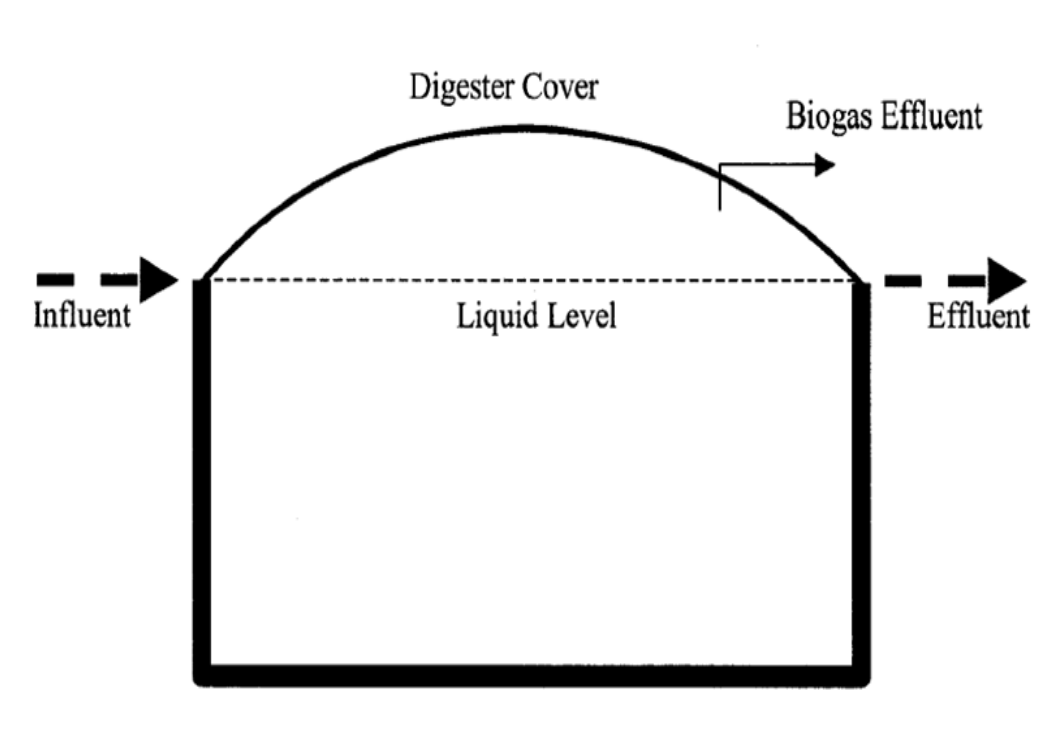

Figure 2. The covered lagoon digester

The complete mix digester, shown in Figure 3, utilizes a large tank with a mixing apparatus to eliminate slurry separation. A set of mechanical arms continually rotating to ensure proper mixture are most often used to allow maximum methane production. Some complete mix tanks are agitated by injecting gas. The captured methane is blown into the tank to mix the influent. One example of the complete mix digester implementation is on a poultry farm where 70,000 birds produced the influent, which was stored in the tank. The tank capacity was $587 \mathrm{~m}^{3}$, while the entire system produced $470 \mathrm{~m}^{3}$ of biogas daily. The effluent was removed from the tank after approximately 22 to 24 days (Sullivan, 2007). 


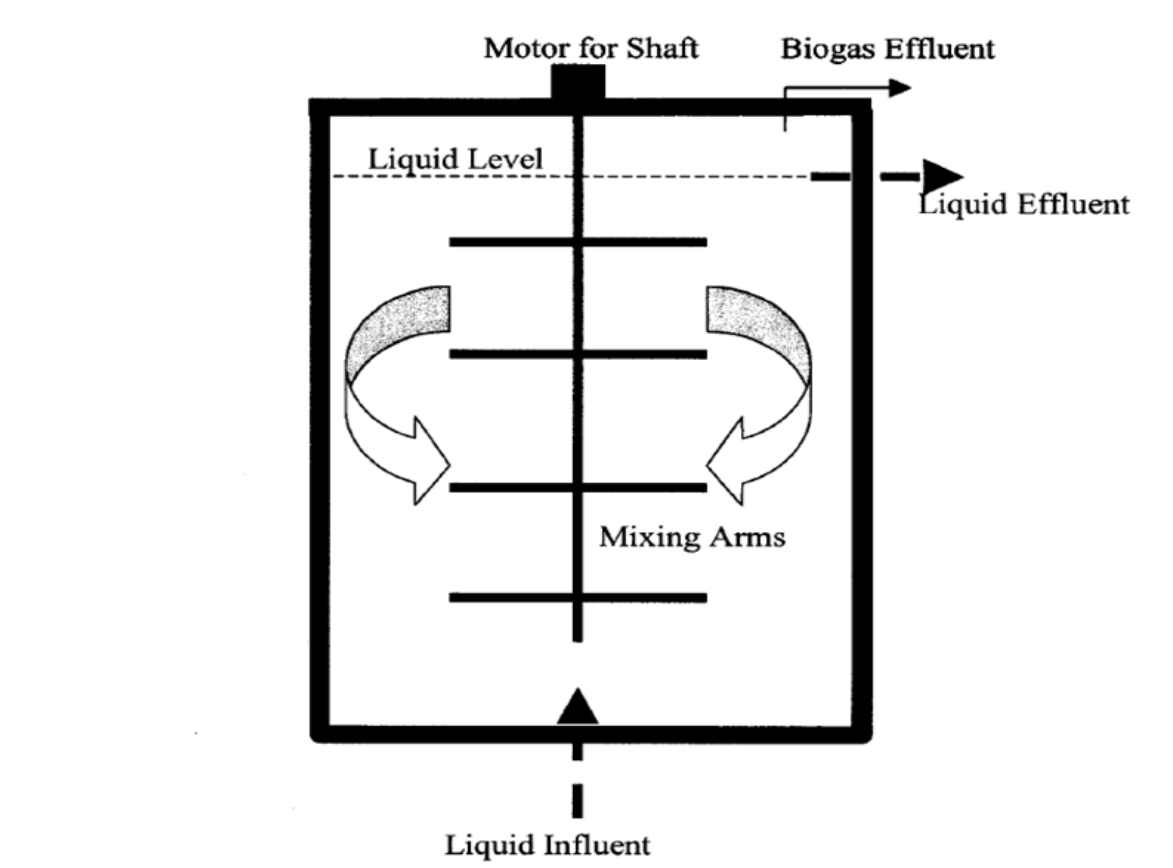

Figure 3. The complete mix digester

The plug flow digester, shown in Figure 4, utilizes the force generated from the influent being deposited into the tank to move the materials through the system. In such a system the gas is collected and moved into the storage tank prior to utilization, and the effluent discharge is collected and processed further, or stored until further disposition.

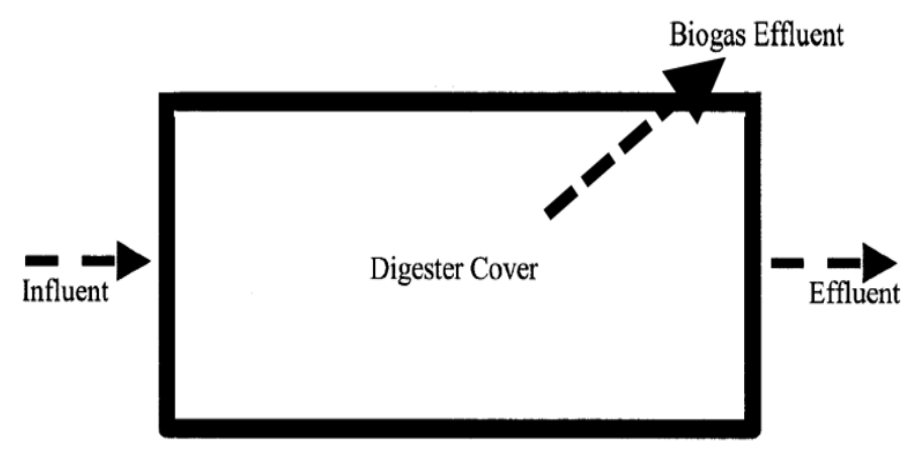

Figure 4. The plug flow digester

The percentage of solids in the slurry mixture is very important for effective digester operation. Operations that require water to flush manure to storage are not ideal for some types of anaerobic digestion. Excessive amount of water not only dilutes the mixture but also slows down the digestion process making methane production inefficient. Bedding used in some operations can be mixed with the manure. Newspapers digest easily, and can increase the production of methane, while bedding containing sand is not compatible with digesters because sand settles down quickly and clogs the system. The manure and liquid are stored together in the digester. As the digestion process is completed, separation allows the liquid to be used as fertilizer, and the solid to be dried and stored for multiple uses. Farms often reuse dried solids for additives to the bedding in the barn (Discover Wisconsin, 2009). 
Anaerobic digesters are designed to treat manure, reduce odor, and capture methane. The time required to process the manure varies depending on the type and size of the digester, the amount of input (influent) produced daily, and the extraction of final output (effluent). Some digesters have a pre-mix tank that ensures the influent is homogenous. This process helps to ensure that the maximum amount of biogas is produced. Once the mixture enters the digestion tank the methane gas is produced is captured. With a system like the plug-flow method, the influent is moved through the tank when the newest batch is allowed to enter. Each batch tends to stick together forming the "plug" which helps maximize the time each portion stays in the digestion tank. In the Midwest, moat digestion tanks are monitored to maintain proper temperature. The temperature of 35 degrees Celsius, which is the most common setting, is maintained by the water piping that runs through the tank. Water is heated in a boiler using some of the captured methane. When the plug reached the far end of the tank it is removed and in many cases the matter is transferred into a separation tank. The liquid portion of the effluent is collected and used for fertilization, and the dry portion is stored where some can be used on the farm while the excess is sold. Pure methane (with no water content) is burned to generate electricity or hot water for other applications or for sale to the utility company.

Figure 5 shows the location of several farm anaerobic digester sites examined in this study with regard to the disposition of manure and generation of methane.

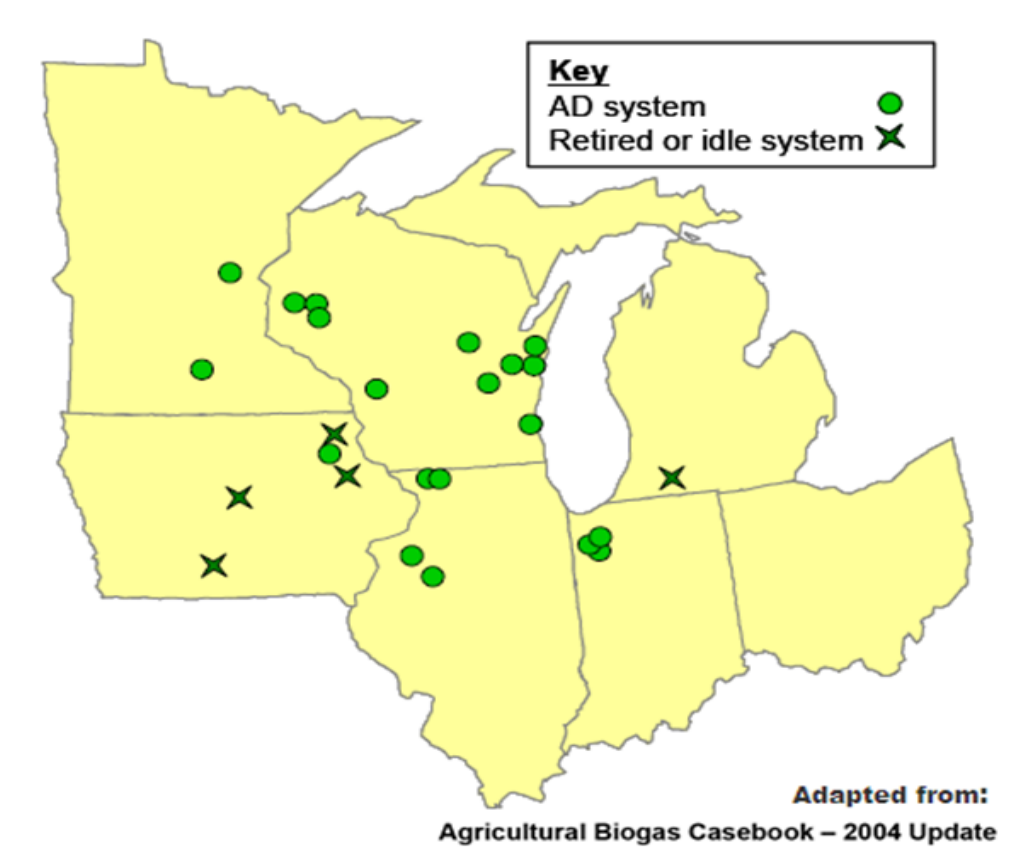

Figure 5. The locations of the anaerobic digesters

The information collected for this study comes from site visits and from outcomes of a study by (Kramer, 2004). Table 1 shows the details of anaerobic digesters included in the study. The subtype of each digestion system is listed with the targeted ranges for solids, the temperature of the manure, and the hydraulic residence time (HRT). The HRT is the amount of time the manure spends in the digester before it is removed.

A total of 26 digesters were studied at 18 locations. The total number of cows was 31,150 . The total number of digesters installed was 26. The average herd size was 1,198. The head per tank ranged from 675 to 2,400 . The farms that have been marked as retired or idle in Figure 5 contain digesters that were not in use at the time the research was conducted. Two idle digesters either recently changed owners or were not being used due to a lack of knowhow or due to the farm with the digester installation being in the sale process. Three retired digesters either developed mechanical and structural problems that were too expensive to fix or the farm operations have changed their production profiles reducing manure production below the required minimum level of input required by the digester (Kramer, 2004). 


\begin{tabular}{|c|c|c|c|}
\hline \multicolumn{4}{|c|}{ Anerobic Digesters in the Midwest } \\
\hline Farm Name & $\begin{array}{l}\text { Farm Type (Head } \\
\text { Feeding Digester) }\end{array}$ & State & Digester Type Category \\
\hline \multicolumn{4}{|l|}{ Construction } \\
\hline Boss Dairy No. 4 & dairy $(3,400)$ & IN & mixed plug-flow loop (x2) \\
\hline Five Star Dairy & dairy $(910)$ & WI & complete-mix \\
\hline Hunter Haven Farms & dairy $(1,000)$ & IL & mixed plug-flow loop \\
\hline Scheidairy Farms & dairy $(1,000)$ & IL & mixed plug-flow loop \\
\hline Wild Rose Dairy & dairy $(900)$ & WI & complete-mix \\
\hline \multicolumn{4}{|l|}{ Startup } \\
\hline Fair Oaks Dairy & dairy $(3,200)$ & IN & vertical plug-flow $(\mathrm{x} 4)$ \\
\hline \multicolumn{4}{|l|}{ Operational } \\
\hline Baldwin Dairy & dairy $(1,100)$ & WI & covered lagoon \\
\hline Double S Dairy & dairy $(1,100)$ & WI & mixed plug-flow loop \\
\hline Emerald Dairy & dairy $(1,600)$ & WI & covered lagoon \\
\hline Gordondale Farms & dairy (875) & WI & mixed plug-flow loop \\
\hline Haubenschild Farms & dairy $(840)$ & MN & plug-flow \\
\hline Herrema Dairy (formerly Boss) & dairy $(3,750)$ & IN & mixed plug-flow loop (x2) \\
\hline $\begin{array}{l}\text { New Horizons Dairy (formerly } \\
\text { Inwood) }\end{array}$ & dairy $(1,400)$ & II & plug-flow (x2) \\
\hline Northern Plains Dairy & dairy $(3,000)$ & MN & plug-flow (x2) \\
\hline Stencil Farm & dairy $(1,000)$ & WI & plug-flow \\
\hline Tinedale Farms & dairy $(2,400)$ & WI & complete-mix (formerly TPAD) \\
\hline Top Deck Holsteins & dairy (675) & IA & plug-flow \\
\hline Wholesome Dairy & dairy $(3,000)$ & WI & mixed plug-flow (x2) \\
\hline Total: 18 farms & & & Total Digesters: 26 \\
\hline
\end{tabular}

\begin{tabular}{|l|c|l|l|}
\hline \multicolumn{4}{|c|}{ Subtype of Digester and Specifications } \\
\hline Plug-Flow Type & $\begin{array}{l}\text { Design Solids } \\
\text { Content }\end{array}$ & $\begin{array}{l}\text { Target Temp. } \\
\left({ }^{\circ} \mathbf{F}\right)\end{array}$ & $\begin{array}{l}\text { Hydraulic Residence Time } \\
(\text { HRT) }\end{array}$ \\
\hline standard, straight & $9-14 \%$ & $98-105$ & 20 days (one digester is 14 days) \\
\hline mixed, loop & $8-10 \%$ & $100-101$ & 20 days \\
\hline vertical tank & $3-7 \%$ & $95-98$ & 6 days \\
\hline Complete-Mix Type & $\begin{array}{l}\text { Design Solids } \\
\text { Content }\end{array}$ & $\begin{array}{l}\text { Target Temp. } \\
\left({ }^{\circ} \mathbf{F}\right)\end{array}$ & $\begin{array}{l}\text { Hydraulic Residence Time } \\
\text { (HRT) }\end{array}$ \\
\hline tank (former TPAD) & $9-10 \%$ & 100 & 20 days \\
\hline tank (thermophilic) & $6-8 \%$ & 135 & 20 days \\
\hline
\end{tabular}

Table 1. The anaerobic digesters included in the study (adapted from Kramer, 2004)

The device operational temperature ranges are referred to as mesophilic. The range for mesophilic digestion is 35 to 40.5 degrees Celsius and 54.4 to 57.2 degrees Celsius is referred to as thermophillic digestion. The mean HRT for dairy manure is 20 days. Although shorter HRT times have been used, it is more desirable to maximize methane production and build tanks large enough to achieve around 20 days of digestion. All of the systems studied have been operated continuously to allow for constant flow of manure loads through the system. Batch fed systems have also been studied but it was found that load and digestion times tie up the tanks for too long. In such systems secondary tanks for holding waste were necessary prior to digestion and with poor mixing conditions, the efficiency of batch fed digesters fell far below that of continuous feed systems (Department for Environment, Food and Rural Affairs, 2005).

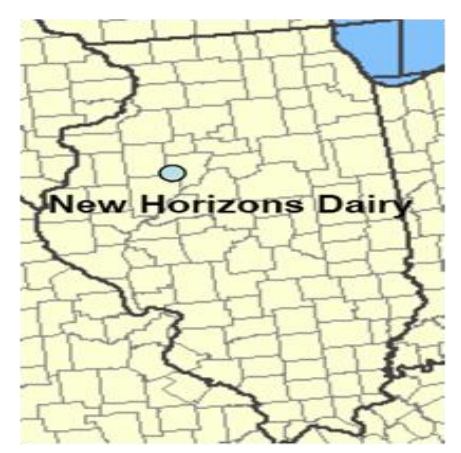




\section{A NEW HORIZONS DAIRY CASE STUDY}

The New Horizons Dairy from Elmwood, Illinois is used as an illustrative case study. At the time of this study the New Horizons Dairy had around 1,100 cows and a total heard of 1,400. The total daily manure production from this herd was approximately $144 \mathrm{~m}^{3}$. The manure was input daily into the system where it is mixed with two loader buckets of other wastes including haylage, cooking grease, and other crop wastes to improve overall biogas output. The percentage of solid matter in the digester was approximately 15 percent.

The operation had two operational plug-flow anaerobic digesters with target temperatures of 40.6 degrees Celsius. The systems were designed to hold wastes for 20 days, but current operations allow the manure to digest for a little over 21 days. The solid percentage of 15 percent is a little above targeted amounts, and some of the increased amounts are on account of the rice hulls being supplemented for bedding. Below is a picture of these digesters. They are the parallel objects in the right half of the picture. They are mostly underground with about $0.30 \mathrm{~m}-0.48 \mathrm{~m}$ of the digester wall above ground. The operational data that is summarized in Table 2 was collected over a period of 1 year.

\begin{tabular}{|ll|ll|}
\hline Farm Name: & New Horizons Dairy & Location: & Elmwood, IL \\
\hline Farm Type: & dairy & Herd Size: & $\begin{array}{l}1,100 \text { lactating, 1,400 } \\
\text { total }\end{array}$ \\
\hline Collection Method: & scrape w/skid steer & Bedding Type: & rice hullls (temporary) \\
\hline Digester Type: & plug-flow (x2) & Design Temperature: & $105^{\circ} \mathrm{F}$ \\
\hline Digester Notes: & combined phase, mesophilic, flexible cover, shared heated wall \\
\hline Design Capacity: & 2,000 head & Date Operational: & November 2002 \\
\hline Design HRT: & 20 days & Current HRT: & $>21$ days \\
\hline Design solids \% & $11-14 \%$ & Current solids \%: & $13-17 \%$ \\
\hline Biogas Use: & electricity, heat (260 kW) & Utility Contract: & no \\
\hline Solids Separation: & yes, post digestion, Fan separator & Solids Use: & was bedding, now field \\
\hline Farm Owns: & digester, energy generation & Utility Owns: & na \\
\hline Digester Designer: & RCM Digesters, Inc. & Utility: & AmerenCILC0 \\
\hline Performance Data & 115,000 cfd (variable herd pop.) & Measuring Period & 12 months (10/02-10/03) \\
\hline
\end{tabular}

Table 2. The data and operational characteristics of the New Horizons Dairy

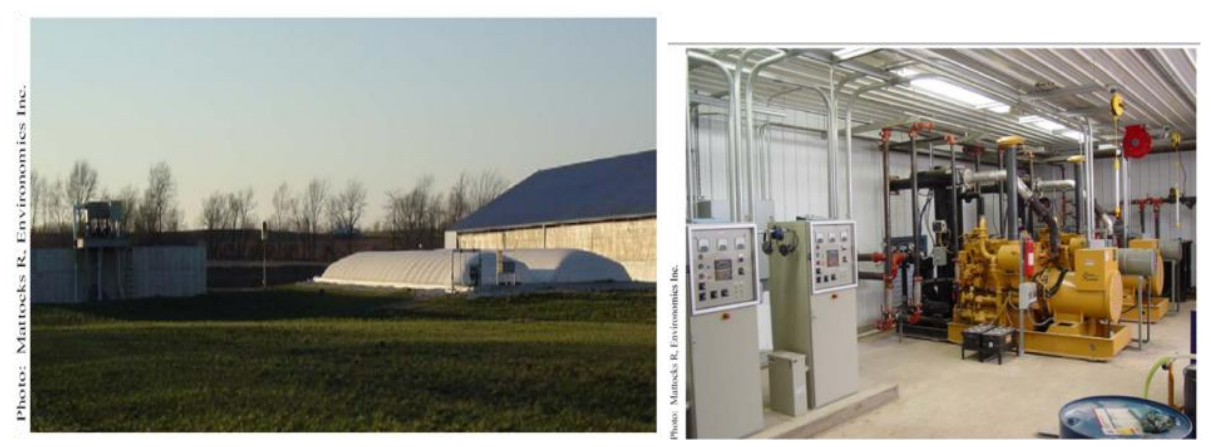

Figure 6. Plug-flow digesters and twin generators at New Horizons dairy

The digesters were designed to operate with a capacity of 2,000 head. New Horizons Dairy was operating with 1,400 head which explained why the HRT timing was over 21 days. Management at New Horizons have been increasing their number of milking cows, but couldn't be reached for an updated interview. Each of the digesters were designed and constructed to hold about $1,514 \mathrm{~m}^{3}$ of material. The digesters measure $24.4 \mathrm{~m}$ wide, $33.5 \mathrm{~m}$ long and are $3 \mathrm{~m}$ deep (Figure 6). 
The dual engine room at New Horizons includes Caterpillar engines each with a capacity to generate 130 KWh of electricity. With the herd size lower than planned, the current output of the engines are $74 \mathrm{KWh}$ and 100 $\mathrm{KWh}$ for a combined output of $174 \mathrm{KWh}, 86 \mathrm{KWh}$ less than capacity. The farm reported that the digester system had been in operation 100 percent of the time for the year it was being studied, with at least one engine running 99 percent of the time and both engines running about 71 percent of the time. Down time is required for regular maintenance and routine checkups. The owners of New Horizons Dairy are happy with the system, and the only change they would have done was to locate the generators closer to the digester. Estimations during the year of the study show that about 521.5 tons of methane or the equivalent of 10,430 tons of carbon dioxide were captured and utilized in the process. The New Horizons Dairy plans to reach their digester capacity of 1,600 head. During the 12 months they were monitored, they estimate to have produced 1.5 million $\mathrm{kWh}$ of electricity.

\section{THE COST OF IMPLEMENTING A DIGESTER SYSTEM}

We compare multiple set up costs, evaluate how different systems fluctuate with power generation, and analyze the costs per cow to evaluate financial feasibility of a digester. The cost analysis was conducted based on data obtained from operations shown in Table 3.

\begin{tabular}{|l|c|c|c|}
\hline \multicolumn{1}{|c|}{ Location } & Total Cost & Herd Size & Cost per Head \\
\hline AA Dairy & 240,000 & 1,000 & $\$ 240.00$ \\
\hline Craven Dairy & 252,848 & 1,000 & $\$ 252.85$ \\
\hline Double S Dairy & 500,000 & 1,100 & $\$ 454.55$ \\
\hline Emerald Dairy & 125,000 & 1,600 & $\$ 78.13$ \\
\hline Gordondale Dairy & 520,000 & 875 & $\$ 594.29$ \\
\hline Haubenschid Farms & 355,000 & 840 & $\$ 422.62$ \\
\hline Stencil Farms & 500,000 & 1,000 & $\$ 500.00$ \\
\hline Top Deck Holsteins & 501,500 & 675 & $\$ 742.96$ \\
\hline Averages & $\mathbf{3 7 4 , 2 9 4}$ & $\mathbf{1 , 0 1 1}$ & $\mathbf{4 1 0 . 6 7}$ \\
\hline
\end{tabular}

Table 3. Costs to get the digesters operational by location

The average herd size was slightly above the 1,000 head mark. The average cost to build a system was $\$ 374,294$, or $\$ 410.67$ per animal. According to the EPA's AgStar program the average costs for heated anaerobic digesters should range between \$200-400 (Office of Air and Radiation, EPA, 2002). These costs include only device set up and installation. We note that maintenance and variable operation costs over the device lifetime should also be considered to evaluate the device economic performance. A case can be made for more government grants available to reduce the venture risks and to encourage broader technology deployment particularly in small and medium size farms.

Energy production plays a significant role when performing a feasibility study. Table 4 shows numerous utility agencies that offer programs that will purchase the energy that is not needed on farm and diverted into the power grid. The price premium paid varies between $\$ .01$ per $\mathrm{kWh}$ to $\$ .035$ per $\mathrm{kWh}$ depending on farm location. The power output from the biogas generators fluctuates from day to day. Methane production rate is not constant and manure temperature and solid concentration play an important role in the amount of methane collected from the system. Hence, dairy operations contract with utility companies to ensure consistent sales of energy derived from farm waste utilization.

The third column in Table 4 demonstrates that the utility companies utilize multiple sources to develop and sustain their eco-friendly image. Since energy utilities are heavily regulated they are required to comply with more stringent minimum standards regarding the percentage of their operations originating from alternative and environmentally friendly sources. 


\begin{tabular}{|c|c|c|c|c|c|}
\hline \multicolumn{6}{|c|}{$\begin{array}{l}\text { State-Specific Utility Green Pricing Programs } \\
\text { (last updated May 2008) }\end{array}$} \\
\hline State & Utility Name & $\begin{array}{l}\text { Program } \\
\text { Name }\end{array}$ & Type & $\begin{array}{l}\text { Start } \\
\text { Date }\end{array}$ & Premium \\
\hline IL & Dairyland Power Cooperative: Jo-Carroll Energy/Elizabeth & $\begin{array}{l}\text { Evergreen Renewable } \\
\text { Energy Program }\end{array}$ & $\begin{array}{l}\text { landfill gas, } \\
\text { biogas, } \\
\text { hydro, wind }\end{array}$ & 1997 & $1.5 \mathrm{c} / \mathrm{kWh}$ \\
\hline IN & Duke Energy & GoGreen Power & $\begin{array}{l}\text { wind, PV, } \\
\text { landfill gas, } \\
\text { digester gas }\end{array}$ & 2001 & $2.56 / \mathrm{kWh}$ \\
\hline IA & $\begin{array}{l}\text { Associated Electric Cooperative, Inc.: Access Eneray } \\
\text { Cooperative, Chariton Vallev Electric Cooperative, Southern } \\
\text { Iowa Electric Cooperative }\end{array}$ & varies by utility & $\begin{array}{l}\text { biomass, } \\
\text { wind }\end{array}$ & 2003 & $\begin{array}{l}2.0 \mathrm{c} / \mathrm{kWh}- \\
3.5 \mathrm{c} / \mathrm{kWh}\end{array}$ \\
\hline IA & $\begin{array}{l}\text { Dairyland Power Cooperative: Allamakee-Clavton/Postville, } \\
\text { Hawkeye Tri-County/Cresco. Heartland Power/Thompson \& St. } \\
\text { Ansqar }\end{array}$ & $\begin{array}{l}\text { Everareen Renewable } \\
\text { Energy Program }\end{array}$ & $\begin{array}{l}\text { hydro, wind, } \\
\text { landfill gas, } \\
\text { biogas }\end{array}$ & 1998 & $3.0 \mathrm{c} / \mathrm{kWh}$ \\
\hline IA & $\begin{array}{l}\text { Lewa Association of Municipal Utilities ( } 84 \text { of } 137 \text { munis offer } \\
\text { program) Afton, Alaona, Alta Vista, Aplinaton, Auburn, } \\
\text { Bancroft, Bellevue, Bloomfield, Breda, Brooklvn, Buffalo, Burt, } \\
\text { Callender, Carlisle, Cascade, Cogaon, Coon Rapids, Corning. } \\
\text { Corwith, Danville, Davton, Durant, Dysart, Earlville, Eldridge. }\end{array}$ & Green City Energy & $\begin{array}{l}\text { wind, } \\
\text { biomass, PV }\end{array}$ & 2003 & Varies by utility \\
\hline MN & $\begin{array}{l}\text { Dairvland Power Cooperative: Freeborn-Mower Cooperative / } \\
\text { Albert Lea. People's / Rochester, Tri-County / Rushford }\end{array}$ & $\begin{array}{l}\text { Everareen Renewable } \\
\text { Eneray Program }\end{array}$ & $\begin{array}{l}\text { hydro, wind, } \\
\text { landfill gas, } \\
\text { biogas }\end{array}$ & 1998 & $1.5 \mathrm{c} / \mathrm{kWh}$ \\
\hline WI & $\begin{array}{l}\text { Dairvland Power Cooperative: Barron Electric, Bayfield/Iron } \\
\text { River, Chippewa / Cornell Valley, Clark / Greenwood, Dunn / } \\
\text { Menomonie, Eau Claire / Fall Creek, Jackson / Black River } \\
\text { Falls, Jump River / Ladysmith, Qakdale, Pierce-Pepin/ } \\
\text { Ellsworth, Polk-Burnett/ Centuria, Price / Phillips, Richland, } \\
\text { Riverland / Arcadia, St. Croix / Baldwin, Scenic Rivers / } \\
\text { Lancaster, Taylor / Medford, Vernon / Westby }\end{array}$ & $\begin{array}{l}\text { Evergreen Renewable } \\
\text { Energy Program }\end{array}$ & $\begin{array}{l}\text { hydro, wind, } \\
\text { landfill gas, } \\
\text { biogas }\end{array}$ & 1998 & $1.56 / \mathrm{kWh}$ \\
\hline WI & $\begin{array}{l}\text { WPPI Energv ( } 34 \text { of } 37 \text { munis offer program): Alaoma, } \\
\text { Cedarbura, Florence, Kaukauna, Muscoda, Stoughton, } \\
\text { Reedsbura, Oconomowoc, Waterloo, Whitehall, Columbus, } \\
\text { Hartford, Lake Mills, New Holstein, Richland Center, Boscobel, } \\
\text { Cuba Citv, Hustisford, Sturgeon Bav, Waunakee, Lodi, New } \\
\text { London, Plymouth, River Falls, Sun Prairie, Waupun, Eaqle } \\
\text { River, Jefferson, Menasha, New Richmond, Prairie du Sac, } \\
\text { Slinger, Two Rivers, Westby }\end{array}$ & $\begin{array}{l}\text { Renewable Eneray } \\
\text { Program }\end{array}$ & $\begin{array}{l}\text { small hydro, } \\
\text { wind, biogas }\end{array}$ & 2001 & $1.0 \mathrm{c} / \mathrm{kWh}$ \\
\hline WI & Wisconsin Public Service & NatureWise & $\begin{array}{l}\text { wind, landfill } \\
\text { gas, biogas }\end{array}$ & 2002 & $1.86 \mathrm{e} / \mathrm{kWh}$ \\
\hline
\end{tabular}

Table 4. A comparison of state incentive programs for selected Midwestern states

\section{RESULTS AND DISCUSSION}

Three dairy farms studied made available detailed performance data. They produce $1,194 \mathrm{kWh}$ of electricity annually per cow that contributes to the digestion process. With the increasing cost of electrical energy they have the potential to be profitable particularly for large herd size that utilizes economies of scale. With the increased pressure/requirement placed on electric companies to buy alternative energy, anaerobic digestion systems may prove to be a sound way for dairy operations to diversify their revenue streams and to reduce costs or their primary operations. For example, the New Horizons dairy has operated with a herd size of 1,400 with 1,100 cows contributing to the system. The contribution rate of 80 percent is typical for farms of this size.

\section{Performance Data}

\begin{tabular}{|l|l|r|}
\hline Farm & $\begin{array}{l}\text { Electricity Production/ } \\
\text { Period of measure }\end{array}$ & $\begin{array}{l}\text { kWh/Cow/ } \\
\text { Year }\end{array}$ \\
\hline Gordondale Farms (dairy) & $\begin{array}{l}876,051 \mathrm{kWh} / \\
12 \text { months }\end{array}$ & 1,208 \\
\hline Haubenschild Farms (dairy) & $1,095,000 \mathrm{kWh} /$ & 1,304 \\
& 12 months & 1,071 \\
\hline New Horizons (dairy) & $1,500,000 \mathrm{kWh} /$ & \\
& 12 months & \\
\hline
\end{tabular}

Table 5. Performance data for the selected farms 


\begin{tabular}{|l|l|}
\multicolumn{1}{|c|}{ Operational Benefits } \\
\hline \multicolumn{1}{|c|}{ Farm Name } & Annual Benefits Savings or Revenues \\
\hline Baldwin Dairy & $\begin{array}{l}\text { odor controlled, volume needing treatment reduced due to precipitation exclusion, } \\
\text { easier handling of digested manure }\end{array}$ \\
\hline Double S Dairy & \$30,000 savings using digested solids for bedding \\
\hline Emerald Dairy & $\begin{array}{l}\text { odor controlled, volume needing treatment reduced due to precipitation exclusion, } \\
\text { easier handling of digested manure }\end{array}$ \\
\hline Gordondale Farms & $\begin{array}{l}\text { \$23,000 in biogas sales (based on kWh of electricity generated), \$30,000 savings } \\
\text { replacing commercial fertilizer with digested manure, \$28,800 savings using digested } \\
\text { solids instead of sand, reduced need for pest control in barns saving \$5,000 per year, } \\
\text { \$2,000 in reduced propane use, herbicide savings (not yet calculated), less lime needed } \\
\text { to balance pH in soil, significant odor control, extra heat allows use of warm flush } \\
\text { flumes and daily scraping throughout the year }\end{array}$ \\
\hline Haubenschild Farms & $\begin{array}{l}\text { \$66,000 in electricity sales and offsets, \$50,000 savings replacing commercial fertilizer } \\
\text { with digested manure, \$30,000 savings in reduced herbicide use, \$4,000 in reduced } \\
\text { propane use, less stirring needed, better neighbor relations, improved operational } \\
\text { flexibility }\end{array}$ \\
\hline New Horizons & $\begin{array}{l}\text { \$40,700 in electricity sales and offsets, process heat allows use of hydronics system, } \\
\text { odor greatly reduced }\end{array}$ \\
\hline Stencil Farm & $\begin{array}{l}\text { electricity offsets, bedding cost savings, odor reduction, improved fertilizer quality of } \\
\text { manure }\end{array}$ \\
\hline Tinedale Farms & \begin{tabular}{l} 
\$7,000 saved using digested solids for bedding \\
\hline
\end{tabular}
\end{tabular}

Table 6. Operational benefits o fusing anaerobic digestion systems at selected farms

With energy premiums dependent on multiple factors, it is difficult to derive a reliable estimate of an average price paid to the farm. Some energy companies will often supply the generation equipment to the operation. This arrangement affects the price, and data consistency. However, a typical Midwest prices for organic energy generated by farms range from 1 cent per $\mathrm{kWh}$ to over 3 cents per $\mathrm{kWh}$. An average of 2 cents was used to evaluate the technology feasibility.

Haubenschild Farms were able to contract with their electric utility company at a premium price of $\$ 0.073$ per kWh with the net benefit of selling excess energy was about $\$ 80,000$ annually. They also noted that operation of the digester saved nearly $\$ 30,000$ because the digester destroyed weed seeds that normally would have germinated in the fields and had to be dealt with chemically. The secondary savings realized for having the manure as more efficient fertilizer was close to $\$ 60,000$ per year. They noticed that due to organic manure treatment the crops were significantly healthier compared to those treated by chemical pesticides. Further, they were able to collect and process the waste at more suitable times resulting in a significant reduction of odor contamination. Similarly, Gordondale Farms produced 876,051 kWh over a 12 month period, which generated total gross revenue of $\$ 17,521.02$ while the New Horizons operation with 2 digesters in operation produced 1,500,000 $\mathrm{kWh}$ of electricity and earned $\$ 30,000$. The net revenue at each farm was lower due to internal electricity consumption. Gordondale Farms reported earnings of $\$ 23,000$ through Alliant Energy. They also have generated savings of $\$ 28,000$ annually on bedding by utilizing the dry effluent digester process by-product for this purpose instead of having to purchase bedding on the market.

Table 6 lists other benefits are listed as reported from the operators of the selected dairy farms.

The monetary value estimates alone cannot be confidently placed on all of the system benefits. The exact economic value of "green" farming is yet to be fully realized and documented. However, current pollution accumulation generated by many chemical applications used on farms is at a level that endangers many species, including humans. At present the costs to build and operate anaerobic digesters remain high making the digester technology investment difficult to justify particularly for small and medium size farms. The earthed lagoon solution is the cheapest to deploy yet it costs a minimum of $\$ 70,000$ to purchase and setup with larger operations costing well over a million dollars. Determination and focus need to be the motto for anyone wanting to implement a digestion 
system. The reported primary and secondary benefits of deploying the anaerobic digestion process in farm operations are as follows:

- $\quad$ Fertilizer Value. The nitrogen present in manure is naturally in a chemical form, which is difficult for plants to utilize. The anaerobic process breaks down the nitrogen chains into smaller particles that plant life can absorb and use more easily for fast growth and yield production.

- $\quad$ Electricity Generation. This dimension several components.

- First, it reduces the demand for electricity from fossil fuels leading to better management and preservation of natural resources (reducing strip mining, ground subsidence, mining hazards, etc.).

- Second, since less coal/oil/natural gas needs to be burned in power plants, it reduces ground air and water pollution.

- Third, it leads to a better diversification of energy sources and reduces national dependence on imported energy.

- Fourth, as some portion of the digester-derived electrical energy is generated and consumed on farms, it reduces pressure on the capacity of the electrical power grid.

- Fifth, the usage of organically generated electricity reduces dependency on the often unreliable power grid for the rural farms.

- Sixth, it allows the farm operation to be more reliable and more efficient by reducing farm dependence on externally supplied electrical energy. By law any excess electricity generated on farms can be sold to the local electrical utility company. It is worth noting that the waste from only 5 cows has the capability to produce enough methane daily to generate enough electricity to operate an average household (Discover Wisconsin, 2009).

- Government and Legal. Producers or eco-friendly energy can obtain tax incentives, subsidies and rebates from the Federal and State governments for implementing "green" energy generation technologies, such as manure digesters. This has become a particularly trendy theme during the tenure of the Obama Administration.

- $\quad$ Fly and Odor Control. Manure left in the open air produces terrible odors. As the influent travels through the digester, these odors are captured. Thus, the effluent that is removed from the system has a drastic 97 percent reduction in the level of odor (Gross, 2002). Consequently, the fly population is markedly reduced because manure is not left in the open air. This leads to a marked improvement in the quality of farm life.

- $\quad$ Renewable Energy and Public Image. In an effort to improve/change their public image utility companies are increasingly looking to team up with organizations that produce renewable energy, such as wind, solar, geothermal, tidal, and biogas installations. Such initiatives have been widely publicized particularly following the drastic increase of oil prices in 2008-2009.

This study has shown that anaerobic digesters can be effectively implemented in farm operations with 1,000 cows and smaller. Using the example of the smallest digester included in this study, the Top Deck Holsteins in Iowa, the 600 milking cows contributing to the tank produced biogas containing 60-70 percent methane. The system setup costs were approximately $\$ 500,000$. We note that the project was successfully completed with collaboration between the Dairy (the energy producing business), the National Resource Conservation Service (the government entity providing grants and know-how), and Alliant Energy (the electrical utility company that purchased and distributed excess electrical energy from the farm through their grid.) Through a three-way partnership between government and the business sector the net cost to the farm was reduced. For example, the Top Deck Farm was responsible only for $\$ 93,600$ or less than $20 \%$ of the total project cost. The remainder was covered by government grants and incentives.

Economy of scale issues involved in operating a dairy herd with $500-800$ cows impact the operation of a digester system significantly. With the estimated manure production of $0.11 \mathrm{~m}^{3}$ per head per day, the removal of 100 cows means that $10.9 \mathrm{~m}^{3}$ less manure would be produced. To keep the digester producing methane with optimal HRT (20 days), the tank size would have to be reduced, and the operation would have to deploy a smaller electrical generator. If the use and installation of the anaerobic digester was not just to produce secondary income but rather mitigate and eliminate environmental hazards, a 500 head operation would be able to support a single digester system. Another way to allow smaller farms to benefit from this technology and to provide a stable supply of manure to the system would be to encourage farmers to form a cooperative group willing to share the tangible 
system benefits and divide the costs of a digester system acquisition, installation, setup, and operation.

\section{CONCLUSION}

In this study we presented a study of anaerobic digesters and their implementation in agricultural settings. A growing number of farms containing large numbers of livestock bring a challenge to the environment. With "green" initiatives gaining popularity, eco-friendly handling and disposal of waste produced on farms becomes critical. Proper manure handling is crucial to acceptance in the community, and can help reduce the volume of greenhouse gasses improving quality of rural life.

We described how the use the anaerobic digestion process to produce methane to generate electricity. We also discussed how farms can use the resources they currently dispose of to fuel the digesters in an economic process that has the potential to benefit their operation and positively affect the surrounding community. Presently used manure handling practices are not the most efficient and friendly to the environment. We provided examples of how anaerobic digesters can solve this problem through heat, energy, and organic decomposition. A broad implementation of the technology requires tighter collaboration between business, university and government entities to help offset significant fixed and operational costs and to keep the environment clean. Data show that the setup and operational costs create an economic entry barrier relating to deployment of farm waste utilization technologies. Digester technology can be economically deployed on small and medium size farms when assistance from government agencies is provided to cover a portion of the technology cost. The Environmental Protection Agency (EPA) has several programs designed to help defray the initial costs of system implementation.

\section{REFERENCES}

1. Achkari-Begdouri, A. P (1989). Anaerobic Digestion of Dairy Cattle Manure Auto heated by Aerobic Pretreatment. Minneapolis- St Paul: University of Minnesota.

2. Anonymous (2009, March 08). Anaerobic Digestion. Retrieved March 10, 2009, from anaerobicdigestion.com: http://www.anaerobic-digestion.com/html/anaerobic flow diagram.html

3. Cascio, J (2005, May 12). World Changing Archives. Retrieved March 17, 2009, from World Changing: http://www.worldchanging.com/archives/002708.html

4. Croisant, D. E (2007). Design and Evaluation of an Anaerobic Digestion System for the Treatment of Dairy Cattle Manure; Knigge Farms LLC. Milwaukee: Milwaukee School of Engineering.

5. David P. Chynoweth, R. I (1987). Anaerobic Digestion of Biomass. Gainesville: Springer.

6. Department for Environment, Food and Rural Affairs (2008). An Assessment of the Environmental Impacts of Organic Farming. London: DEFRA.

7. Department for Environment, Food and Rural Affairs (2005). Assessment of Methane Management and Recovery Options for Livestock Manures and Slurries. London: DEFRA.

8. Discover Wisconsin (2009, March 15). America's Dairyland - Perception versus Reality. Eagle River, Wisconsin, USA: Discover Mediaworks, Inc.

9. Energy, BioCycle- (2003, January). Jobwerx Industry Archives. Retrieved March 17, 2009, from Jobwerx.com: http://www.jobwerx.com/news/Archives/electricity022603.html

10. Farrell, J (2008). Minnesota Feed-In Tariff Could Lower Cost, Boost Renewables and Expand Local Ownership. Minneapolis: Institute for Local Self-Reliance.

11. Gross, R (2002). Haubenschild Farms Anaerobic Digester. St Paul: The Minnesota Project.

12. Hansen, C. A (2007). Fermentation, Biogas and Biohydration Production from Food Waste. Waste Management and Co-product Recovery in Food Processing 4, 7-28.

13. Intergovernmental Panel on Climate Change (2007). Climate Change 2007: Mitigation for Climate Change. Geneva: IPCC Secretariat - WMO.

14. Joaquan Vaquez, S. L (2008). Evaluating Digester Design for Electricity Generation. BioCycle, 51-53.

15. Kanter, J (2007, June 20). Carbon Trading: Where greed is green. International Herald Tribune, p. 2.

16. Kramer, J. M (2004). Experiences with Agricultural Biogas Systems 2004 - Update. Madison: Resource Strategies, Inc.

17. Kurt Roos, H. Z (2004). Funding On-Farm Biogas Recovery Systems, A Guide of Federal and State Resources. Washington D.C.: Environmental Protection Agency. 
18. Labortory, N. R (2008, September 10). US Department of Energy - Green Power Markets. Retrieved March 18, 2009, from US Department of Energy - energy Efficiency and renewable Energy: http://apps3.eere.energy.gov/greenpower/markets/pricing.shtml?page $=1$

19. Nordhaus, W (2008). A Question of Balance. New Haven \& London: Yale University Press.

20. Office of Air and Radiation, EPA (2002). Managing Manure with Biogas Recovery Systems, Improved Performance at Competitive Costs. Washington D.C., Environmental Protection Agency.

21. Office of Chief Economist (2002). Greenhouse Gas Inventory; 1990 - 2001. Washington D.C.: USDA.

22. Schneider, A. M (2006). Production of electrical Energy and Heat from Fuel Cells Using Bio-Gas; Waukesha Wastewater Treatment Facility. Milwaukee: Milwaukee School of Engineering.

23. Simich, J. M (2004). An Economic Analysis of Using Thermophillic Anaerobic Digestion Followed by Ultrafiltration for the Treatment of Dairy Wastes. Milwaukee: Milwaukee school of Engineering.

24. Sullivan, G. W (2007). Biogas Vehicle Fuel From Digested Cattle Manure. Logan, Utah: Utah State University.

25. United States Environmental Protection Agency (2009, March). U.S. EPA AgStar Program. Retrieved March 17, 2009, from AgStar Program: http://www.epa.gov/agstar/index.html

26. Vencat, E. F (2007, Web Exclusive). The Carbon Folly. Newsweek, p. 2.

27. Voss, J.-P (2007). Innovation Processes in Governance: The Development of Emissions Trading as a New Policy Instrument. Science and Public Policy, 329-343.

28. Zehnder, J. B (1988). Biology of Anaerobic Microorganisms. New York: John Wiley \& Sons Inc. 


\section{NOTES}

